\section{SUPPRESSION OF SYMPATHETIC NERVOUS FUNCTION IN LOW-RENIN ESSENTIAL HYPERTENSION}
M. ESLER
A. ZWEIFLER
O. RANDALL
S. Julius
J. BENNETT
P. RYDELEK

Hypertension Section, University of Michigan Medical Center, Ann Arbor, Michigan, U.S.A.

\section{E. COHEN}

Section of Endocrinology and Metabolism, University of Michigan Medical Center, Ann Arbor

\section{DeQuattro}

Department of Medicine, University of Southern California Medical Center, Los Angeles, California

Summary Study of general hæmodynamics in 15 patients with low-renin essential hypertension showed hæmodynamic and pathophysiological heterogeneity. However, there was suppression of sympathetic nervous system function in all low-renin patients, regardless of hæmodynamic pattern. Subnormal sympathetic nervous activity was manifested by a low normal mean plasma-noradrenaline concentration at rest, diminished noradrenaline responsiveness to postural stimulation, and a reduced blood-pressure response to the indirectly acting sympathomimetic amine tyramine. It is proposed that the syndrome of low-renin essential hypertension is of diverse ætiology, but with secondary sympathetic nervous system underactivity as a feature common to the various forms. The low plasmarenin activity is probably an expression of defective sympathetic nervous system stimulation of renin release.

\section{Introduction}

SOME patients with essential hypertension have low plasma-renin activity (P.R.A.). ${ }^{12}$ Despite continuing investigative interest, the pathophysiology of these "lowrenin hypertensives" remains uncertain. There are probably several distinct mechanisms responsible for the renin suppression in this syndrome. Excessive adrenal mineralocorticoid secretion, ${ }^{34}$ increased central ("effective") blood-volume, ${ }^{56}$ and progressive reduction in P.R.A. with time in severe or longstanding essential hypertension ${ }^{78}$ have all been found.

Since the sympathetic nervous system has an important modulating influence on renin release, ${ }^{9}$ it seemed possible that the final common pathway for renin suppression in the various forms of low-renin hypertension might be sympathetic nervous system underactivity. ${ }^{8} 10$ This possibility was explored using biochemical and pharmacological indices of sympathetic nervous system function.

\section{Patients}

Thirty-two hypertensive patients were recruited from the hypertensive and endocrinology services of the University of Michigan Medical Center. All were male and aged between 20 and 50 years. Average casual blood-pressure was above 155 $\mathrm{mm} \mathrm{Hg}$ systolic or $95 \mathrm{~mm} \mathrm{Hg}$ diastolic, or both. Investıgations performed, including estimation of urinary aldosterone excretion, adequately excluded a diagnosis of secondary hypertension. The renin status of the hypertensives was categorised as "normal" or "low" by reference of P.R.A. values on an unrestricted diet, after $1 \mathrm{~h}$ standing, and $24 \mathrm{~h}$ urinary sodium excretion (urine collection in a metabolic ward), to renin and sodium values in forty-one age-matched normal male volunteers. ${ }^{11}$ P.R.A. was measured using a radioimmunoassay of angiotensin I generated in vitro. ${ }^{12}$ All hypertensives and twelve of the normal subjects were recruited into the study now to be described. All subjects read and signed an informed consent form outlining the details of the tests to be performed.

\section{Materials and Methods}

Measurement of general hæmodynamics and blood-volumes was done at rest in all subjects, after they had remained recumbent in hospital overnight, using methods previously described. ${ }^{13}$ Cardiac output was measured by dye dilution, intraarterial blood-pressure was recorded after percutaneous puncture of the brachial artery, central (effective) bloodvolume was derived from the cardiac output and mean transit time of the indicator dye, ${ }^{13}$ with dye delivery into the right atrium via a Swan-Ganz catheter and dye sampling from the brachial artery. Plasma volume was estimated using Evans blue. From this, and the arterial hæmatocrit, total bloodvolume was calculated.

Sympathetic nervous system function was then studied in ten of the hypertensive patients with normal F.R.A., in eight patients with low P.R.A., and in eight normal subjects. All investigations were carried out with subjects in sodium balance, after a minimum of 5 days on a sodium intake of $160 \mathrm{mmol}$ daily in a metabolic ward. Plasma-noradrenaline concentration in venous blood was measured by the fluorimetric assay of Renzini et al. ${ }^{14}$ after a $2 \mathrm{~h}$ supine rest and after $12 \mathrm{~min}$ of $35^{\circ}$ head-up tilting on a tilt-table. Plasma-noradrenaline was estimated blind by one of us (V. DeQ.) without knowledge of the diagnosis.

Next the intra-arterial blood-pressure-response to the sympathomimetic agent tyramine was studied. Tyramine is an indirectly acting amine, having pressor activity only through its ability to release noradrenaline from sympathetic nerve endings. ${ }^{15}$ Tyramine hydrochloride was administered by rapid intravenous injection in doses of $0.75 \mathrm{mg}, 1.5 \mathrm{mg}$, and $2.5 \mathrm{mg}$. Blocking doses of propranolol $(0.2 \mathrm{mg} / \mathrm{kg})$ and atropine $(0.04$ $\mathrm{mg} / \mathrm{kg}$ ) were administered before tyramine to abolish tyramine effects on the heart and reflex cardiac responses to the change in blood-pressure produced by the drug: with this experimental design the blood-pressure rise with tyramine was solely dependent on noradrenergic vasoconstriction. The blood-pressure response to intravenous bolus injections of noradrenalıne in doses of 1,2 , and $3 \mu \mathrm{g}$ was then recorded in each patient for comparison with the tyramine responses.

On 2 other days the P.R.A. response to exogenous adrenergic stimulation was studied, using the $\beta$-adrenergic agonist isoprenaline. Isoprenaline stimulates renin release in man, probably by direct action on $\beta$ receptors of the juxtaglomerular cells of the kidney. ${ }^{16}$ Isoprenaline hydrochloride was infused at a rate of $30 \mathrm{ng}$ base $/ \mathrm{kg} / \mathrm{min}$ for $25 \mathrm{~min}$, with sequential sampling of venous blood for estimation of P.R.A. during the infusion. The drug was administered twice to each subject, during the $160 \mathrm{mmol}$ sodium diet, then under conditions of sodium deprivation (sodium intake $10 \mathrm{mmol}$ daily for 6 days).

\section{Results}

\section{Hamodynamics}

Hæmodynamic findings at rest are shown in the accompanying table. Overall the low-renin essential hypertensives were characterised as a group by a normal cardiac output, the higher blood-pressure being maintained by an elevated total peripheral vascular resistance. Heart-rate was marginally, but not significantly, lower than in the normal subjects (table). The mean 
HAEMODYNAMICS AT REST (MEAN \pm S.D.)

\begin{tabular}{|c|c|c|c|c|c|}
\hline- & $\begin{array}{c}\text { P.R.A. } \\
\text { (standing) }(\mathrm{ng} / \mathrm{ml} / \mathrm{h})\end{array}$ & $\begin{array}{c}\text { Mean arterial } \\
\text { pressure }(\mathbf{m m} \mathbf{~ H g})\end{array}$ & $\begin{array}{l}\text { Cardiac index } \\
\left(1 / \mathrm{m} n / \mathrm{m}^{2}\right)\end{array}$ & $\begin{array}{l}\text { Heart-rate } \\
\text { (per min) }\end{array}$ & $\begin{array}{c}\text { Total perpheral } \\
\text { resistance }\left(\mathrm{mm} \mathrm{Hg} / \mathrm{L} / \mathrm{mmn} / \mathrm{m}^{2}\right)\end{array}$ \\
\hline Narmal subjects $(N=12)$ & $2.02 \pm 0.59$ & $87 \pm 6$ & $2 \cdot 74 \pm 0 \cdot 32$ & $62 \pm 9$ & $132 \cdot 3 \pm 5 \cdot 0$ \\
\hline $\begin{array}{l}\text { Essentual hypertension: } \\
\text { Normal renin }(N=17) \\
\text { Low renin }(N=15)\end{array}$ & $\begin{array}{l}2 \cdot 10 \pm 0.68 \\
0.71 \pm 0.31 \dagger\end{array}$ & $\begin{array}{l}105 \pm 15 \dagger \\
118 \pm 18 \dagger\end{array}$ & $\begin{array}{l}2 \cdot 38 \pm 0.55^{*} \\
2.71 \pm 0.56\end{array}$ & $\begin{array}{l}61 \pm 11 \\
56 \pm 8\end{array}$ & $\begin{array}{l}45 \cdot 3 \pm 8 \cdot 7 \dagger \\
43 \cdot 5 \pm 12 \cdot 8 \dagger\end{array}$ \\
\hline
\end{tabular}

I he signuficance levels of the differences between normal subjects and the hypertensive groups are shown. ${ }^{*} \mathrm{P}<0.05, f \mathbf{P}<0.01$ (Student's $t$ test).

hæmodynamic values, however, obscure an underlying hæmodynamic heterogeneity. Three hæmodynamic patterns were recognised. Severe hypertension (resting mean blood-pressure greater than $125 \mathrm{~mm} \mathrm{Hg}$ ) was present in four patients (fig. 1) who had a normal total blood-volume, normal central blood-volume, normal or low cardiac output, and elevated total peripheral vascular resistance. In six patients with mild hypertension and normal total blood-volume, central (effective) bloodvolume was increased (fig. 1 ), with a raised stroke volume and cardiac output $(\mathrm{F}<0.05)$. The remaining five patients with low P.R.A. had a normal central and total blood-volume, normal cardiac output, and elevated total peripheral resistance as the basis for their mild to moderately severe disease.

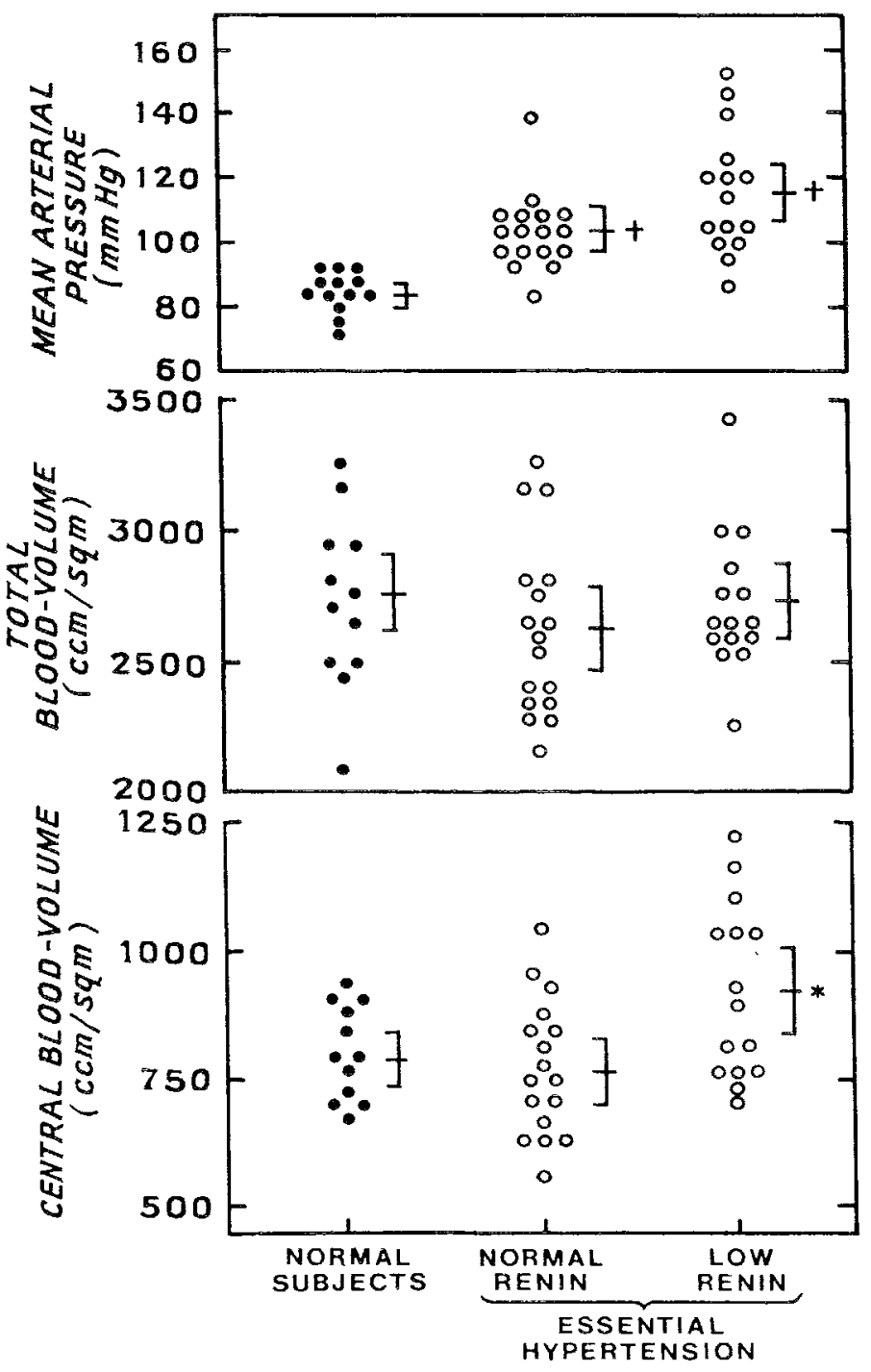

Fig. 1-Arterial pressure and blood-volumes in normal and low-renin hypertensives compared with normal subjects.

Mean values and s.D.s are shown. ${ }^{*} \mathrm{p}<0.05, \mathrm{t} \mathrm{r}<0.01$.

\section{Plasma-noradrenaline Concentration}

Plasma-noradrenaline in normal subjects at rest was $136 \pm 44 \mathrm{ng} / 1$ (mean \pm s.D.) (fig. 2 ). In hypertensives with normal renin, plasma-noradrenaline was $173 \pm 73 \mathrm{ng} / \mathrm{A}$ (difference not significant). In the low-renin essential hypertensives, plasma-noradrenaline at rest was $98 \pm 63$ $\mathrm{ng} / 1$. This was significantly lower than in hypertensives with normal P.R.A. $(\mathrm{P}<0.05)$. Mean plasma-noradrenaline was approximately $30 \%$ lower in the low-renin hypertensives than in normal subjects, but the difference was not significant $(P>0.05)$. However, in three of eight low-renin patients, plasma-noradrenaline was below normal (fig. 2).

Low-renin hypertensives where characterised as a group by diminished sympathetic responsiveness to head-up tilting. In three of eight a vasovagal reaction occurred. There was no change in plasma-noradrenaline with tilting overall $(+2 \pm 102 \mathrm{ng} / 1)$ (fig. 2). Normal subjects and hypertensives with normal P.R.A. both demonstrated approximately a doubling of plasma-noradrenaline with tilting (fig. 2).

\section{Blood-pressure Response to Tyramine}

The rise in blood-pressure with tyramine was diminished in the low-renin hypertensives (fig. 3). At each of the three doses of tyramine used, the pressor re-

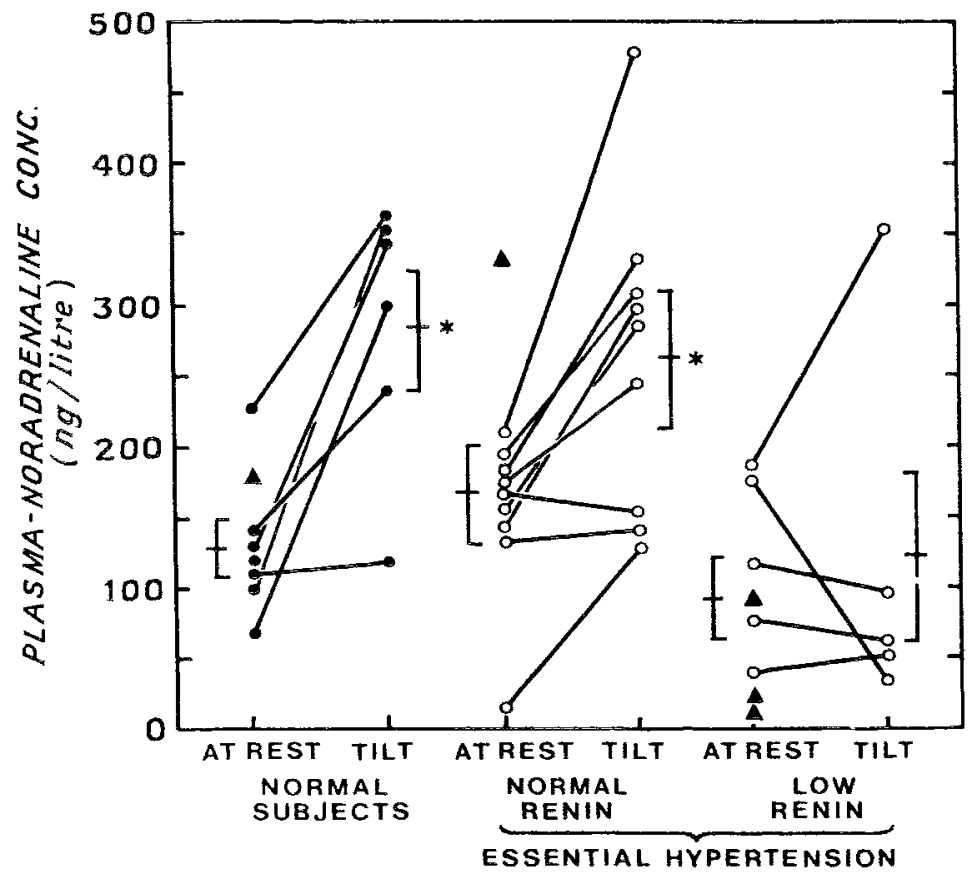

Fig. 2-Plasma-noradrenaline resting and tilted.

Subjects $(\mathbf{A})$ had a vasovagal reaction with tilting, and resting nor adrenaline values only are available. Plasma-noradrenaline rose with tilting in normal subjects and hypertensives with normal plasma-renin (*P 0.01 , paired $t$ test). 
sponse in the low-renin hypertensives was approximately only $30 \%$ of that in the other two groups $(\mathrm{P}<0.02)$. The rise in blood-pressure produced by intravenous injection of noradrenaline was normal in the patients with low P.R.A.

\section{Renin Response to Exogenous Adrenergic Stimulation}

The P.R.A. response to isoprenaline on the $160 \mathrm{mmol}$ sodium diet was marginally, but not significantly, lower in hypertensives with normal renin than in normal subjects (fig. 4). In the low-renin patients, the renin response to isoprenaline was approximately $50 \%$ of normal $(P<0.05)$. This was not an expression of a generalised reduction in $\beta$-adrenergic receptor sensitivity in lowrenin hypertensives, since the heart-rate response to isoprenaline was unimpaired (fig. 4). On the low-salt diet, the P.R.A. response was normal in the normal-renin hypertensives, but clearly subnormal in the low-renin patients (approximately $80 \%$ reduced, $\mathrm{P}<0 \cdot 01$ ).
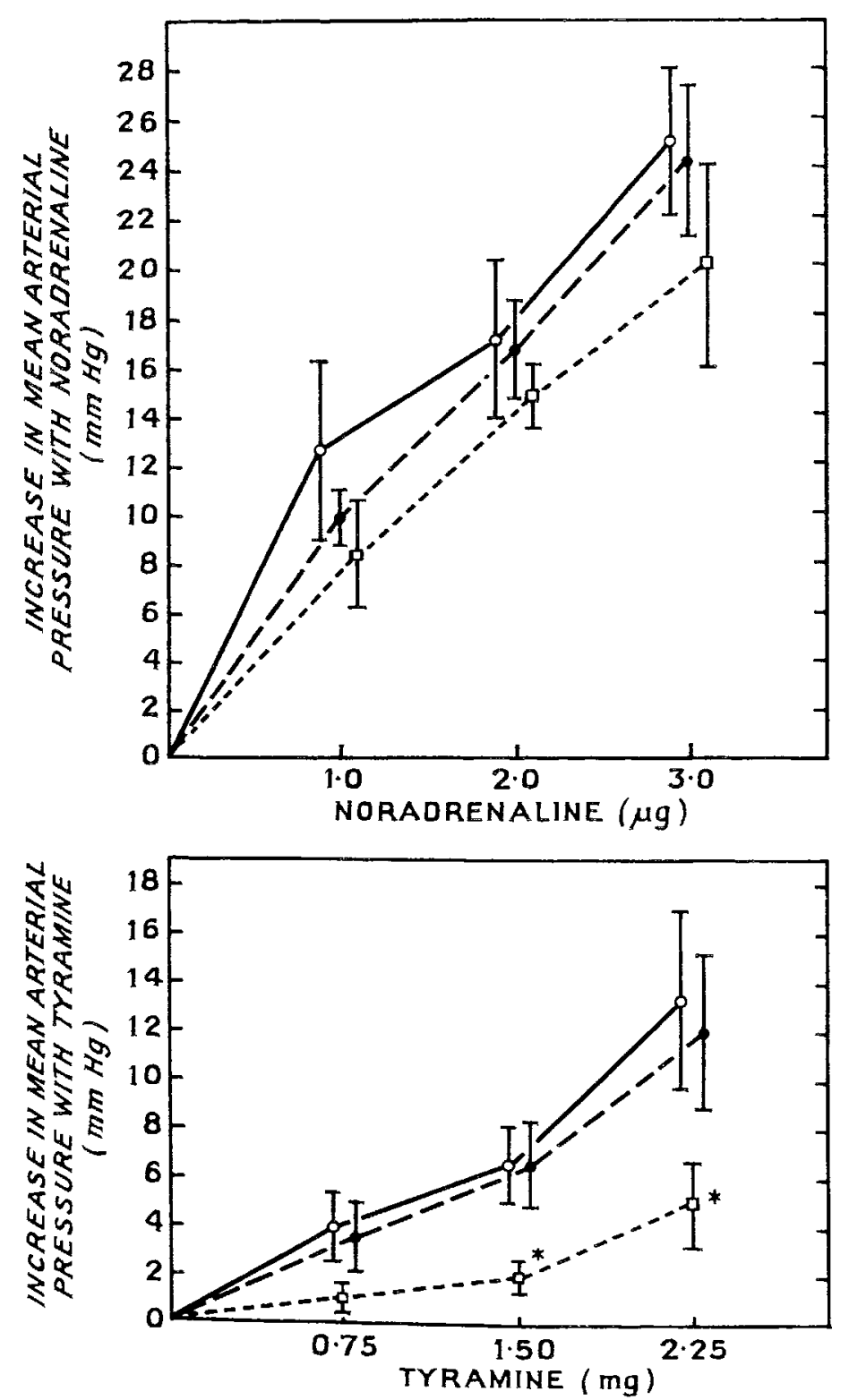

Fig. 3-Blood-pressure responses to tyramine and noradrenaline (after cardiac autonomic blockade with propranolol plus atropine) in hypertensive patients compared with normal subjects.

- - Vurmal subjects

$0=$ Essential hypertension, normal renin.

$==$ Essential hypertension, low renin.

*. - U. 02.

\section{Discussion}

The sympathetic nervous system plays an important role in the control of renin release by the kidney. ${ }^{9}$ This knowledge led to the early suggestion that P.R.A. and sympathetic nervous function may be closely linked in human hypertension. ${ }^{17}$ For patients with mild essential hypertension and elevated P.R.A. this concept now seems established. There is accumulating evidence that in such patients sympathetic nervous system overactivity exists, raising P.R.A. and sustaining the rise in blood-pressure. ${ }^{8} 17-19$

For essential hypertensives with low P.R.A., sympathetic nervous underactivity has been proposed as the basis for the suppression of P.R.A., ${ }^{810}$ but here the evidence is less convincing, although improving. ${ }^{820}$ In the present study, using biochemical and pharmacological indices of sympathetic nervous system function, we found striking evidence of sympathetic nervous underactivity in patients with low-renin essential hypertension.

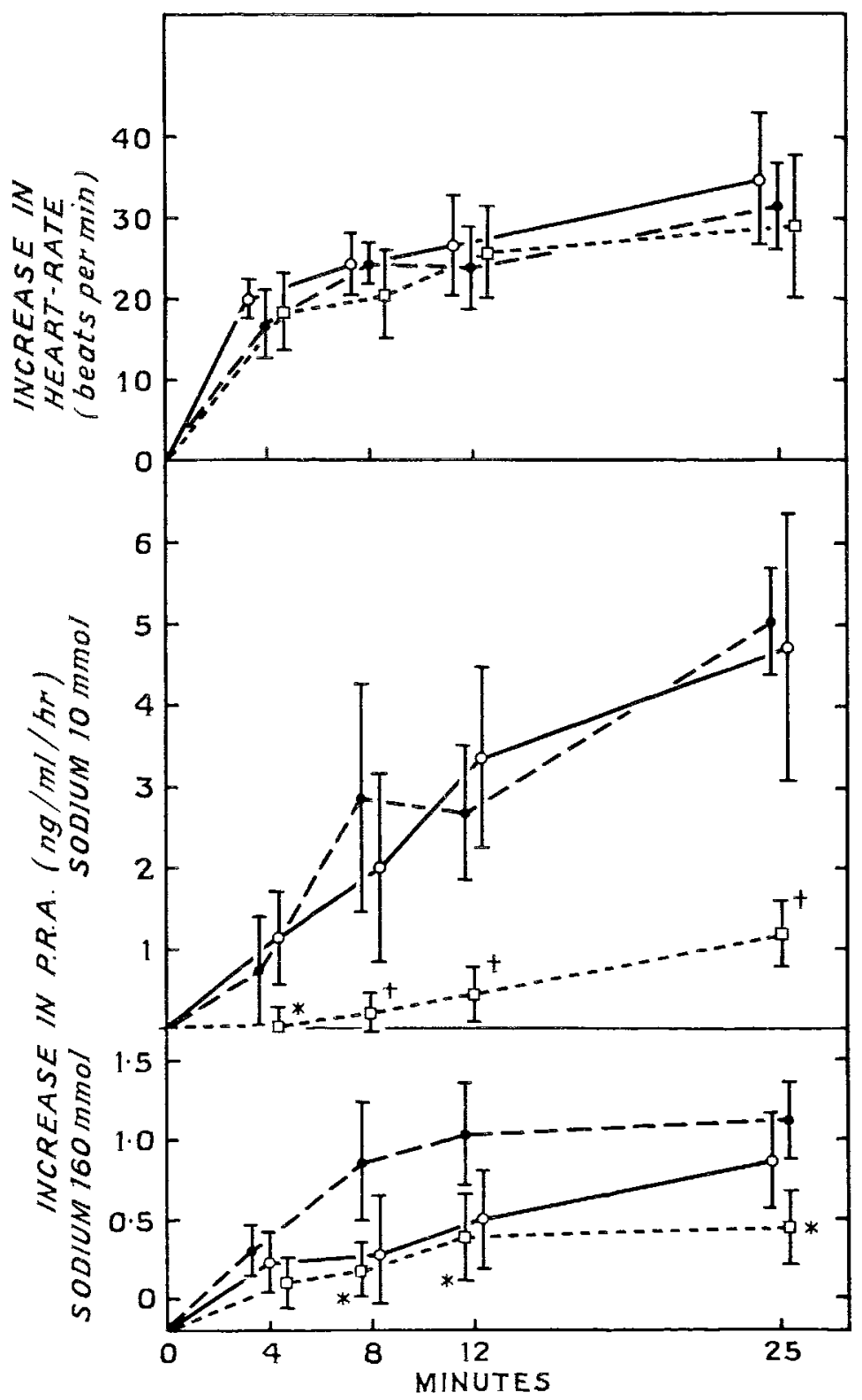

Fig. 4-Changes in P.R.A. and heart-rate with isoprenaline in hypertensive patients compared with normal subjects.

- = Vormal subjects.

$\mathrm{o}=$ Essential hypertension, normal renın

$\square=$ Essential hypertension, low renın.

${ }^{*} \mathrm{P}-0.05 ;+\mathrm{P}<0.01$. 
While the plasma-noradrenaline concentration at rest was subnormal in only a minority of low-renin patients, the noradrenaline response to postural stimulation was much diminished, and the blood-pressure rise with the indirectly acting sympathomimetic amine tyramine was clearly attenuated. Tyramine produces raised bloodpressure by releasing the sympathetic neurotransmitter noradrenaline from sympathetic nerve varicosities, and has been used as a pharmacological tool in the study of sympathetic nerve endings. ${ }^{15}$ The pressor response to tyramine is related to the noradrenaline pool size in the sympathetic nerve ending. ${ }^{15}$ Since the blood-pressure response to intravenous administration of noradrenaline in the low-renin hypertensives was normal, the findings with tyramine suggest either diminished accessibility of tyramine to the sympathetic noradrenaline pools, or, more likely, a diminution in noradrenaline pool size.

With exogenous adrenergic stimulation of renin release, using isoprenaline, the rise in P.R.A. was subnormal in the low-renin hypertensives. This abnormality was accentuated by dietary sodium restriction. There are other reports also of a diminished renin response to pharmacological stimulation with infusion of noradrenaline $\mathrm{e}^{21}$ and theophylline $\mathrm{e}^{20}$ in low-renin hypertension. Therefore the defective sympathetic nervous stimulation of renin release in low-renin essential hypertension may involve two mechanisms: first, decreased sympathetic nerve traffic to the kidney; and second, a reduction in responsiveness to adrenergic stimulation.

Several different mechanisms have been implicated in the pathogenesis of low-renin essential hypertension. Mineralocorticoid excess, ${ }^{3}{ }^{4}$ increased central (effective) blood-volume, 56 and a reduction in P.R.A. with time in severe or longstanding essential hypertension ${ }^{78}$ have all been proposed as explanations of the lower plasmarenin. The hæmodynamic findings in low-renin essential hypertension in this study were varied, suggesting such a pathophysiological heterogeneity. In particular, central blood-volume was increased, without an increase in total blood-volume, in six patients, while four patients had severe longstanding hypertension. Adrenal steroid metabolism was not studied by us, so the existence of non-aldosterone mineralocorticoid hypertension in some of these patients is possible. ${ }^{4}$

These different pathophysiological patterns may all be associated with sympathetic nervous underactivity. Reduced sympathetic responsiveness has been described in severe, longstanding essential hypertension 2223 although the mechanism is uncertain. Primary aldosteronism, which may be considered as the prototype of human mineralocorticoid hypertension, is also associated with diminished sympathetic nervous responsiveness. ${ }^{24}$ In hypertensives with an increase in central blood-volume, ${ }^{56}$ sympathetic nervous underactivity would be expected to follow from stimulation of cardiopulmonary volume receptors by the higher central blood-volume. ${ }^{25} 26$ It is proposed that the syndrome of low-renin essential hypertension is of diverse ætiology, but with secondary sympathetic nervous system underactivity as a feature common to the various forms. The low P.R.A. is probably an expression, at least in part, of defective sympathetic nervous stimulation of renin release.

Requests for reprints should be addressed to M. E., Hypertension
Section, Department of Internal Medıcine, University of Michıgan Medical Center, Ann Arbor, Michigan 48109, U.S.A.

\section{REFRENCES}

1. Kuchel, O., Fishman, L. M., Lıddle, G. W., Michelakis, A. Ann. intern. Med. $1967,67,791$.

2. Crane, M. G., Harris, J. J., Johns, V. Am. f. Med. 1972, 52, 457

3. Woods, J. C., Hili, C., Liddle, G. W., Stant, E. G., Michelakıs, A. M., Brill A. B. Archs intern. Med. 1969, 123, 366.

4. Melby, J. C., Dale, S. L., Wilson, T. E. Crrculatıon Res. 1971, 28, suppl 2,143 .

5. Esler, M., Julius, S., Randall, O. Crrculatzon, 1975, 52, suppl. 2, 55.

6. Esler, M., Julius, S., Randall, O., in The Arterial Hypertensive Disease (edited by $G$. Rorive and $H$. van Cauwenberge); p. 231. Parıs, 1976.

7. Tuck, M., Williams, G., Cain, J., Sullivan, J., Dluhy, R. Am. $\mathcal{f}$ Cardıl. $1973,32,637$

8. Esler, M. D., Nestel, P. J. ibid. p. 643.

9. Vander, A. J.Am. F. Phystol. 1965, 209, 659

10. Collins, R. D., Weinberger, M., Gonzales, C., Nokes, G., Leutscher, J. A Clin. Res. 1970, 18, 167

11. Brunner, H. R., Laragh, J. H., Baer, L., Newton, M. A., Goodwin, F. T. Krakoff, L. R., Bard, R. H., Buhler, F. R. New Engl. F. Med 1972, 286, 441.

12. Haber, E., Koerner, T., Page, L. B., Kliman, B., Purmode, A. F. clin. Endocr $1969,29,1349$

13. Ellis, C. N., Julius, S. Br. Heart f. 1973, 35, 450

14. Renzini, V., Brunori, C. A., Valori, C. Clinica chım. Acta, 1970, 39, 587

15. Harvey, S. C., Sulkowski, T. S., Weenig, D. J. Archs tnt. Pharmacodyn Thér. 1967, 169, 262

16. Esler, M. D. Clin. Pharmac. Ther. 1974, 15, 484

17. Dustan, H. P., Tarazi, R. C., Frohlich, E. D. Circulation, 1970, 41, 555.

18. Esler, M. D., Julius, S., Randall, O. S., Ellıs, C. N., Kashıma, T. Am. F. Car diol. $1975,36,708$.

19. Esler, M., Julius, S., Randall, O., DeQuattro, V., Zweıfler, A. Clin. $S_{c}$ molec. Med. (in the press)

20. Lowder, S. C., Hamet, P., Liddle, G. Circulation Res 1976, 38, 105

21. Jose, A., Crout, J. R., Kaplan, N. M. Ann. intern. Med. 1970, 72, 9.

22. Frohlich, E. D., Tarazi, R. C., Ulrych, M., Dustan, H. P., Page, I. H. Ctrculation, 1967, 36, 387

23. Esler, M. D., Nestel, P. J. Clin. Sci. 1973, 44, 213

24. Biglieri, E. G., Mcllroy, M. B., Naimark, A., Forsham, P H. J. clin. Invest. $1962,41,1345$.

25. Clement, D. L., Pelletier, C. L., Shepherd, J. T. Carculation Res 1972, 31, 824.

26. Pelletier, C. L., Shepherd, J. T. ibid. 1973, 33, 131

\section{CIRRHOSIS IN SOUTH LONDON}

\section{H. J. F. HodGSON* \\ R. P. H. THOMPSON \\ St. Thomas' Hospital, London SE1}

Summary Alcoholism was the major ætiological factor in $65 \%$ of 78 patients presenting with cirrhosis to a hospital in Central London during 1968-74. It is suggested that in the U.K. the importance of alcoholism in patients with cirrhosis has been underestimated.

\section{Introduction}

THERE is little agreement on the relative importance of alcohol in the ætiology of cirrhosis of the liver in the U.K. Surveys in 1966 and 1973 of patients with cirrhosis implicated alcoholism as the primary factor in from $24 \%^{1}$ to $51 \%^{2}$ of cases. This may be partly because the relative importance of alcohol will vary between surveys carried out in specialised centres and those in less specialised district general hospital. Furthermore, the consumption of alcohol in the U.K. has been steadily increasing over the past 20 years, ${ }^{3}$ and so the contribution made by alcohol to liver disease may be expected to rise.

*Present address: Department of Medicine, Royal Free Hospital, London NW'1 